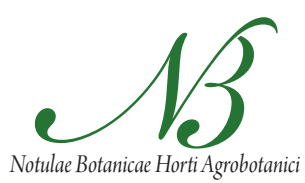

Cluj-Napoca

\title{
The Influence of Varieties and Planting Systems on the Peach Tree Growth, Productivity and NPK Uptake
}

\author{
Traian G. MATEI, Roxana M. MADJAR, Florin STǍNICĂ* \\ University of Agronomic Sciences and Veterinary Medicine, Horticulture Department, 59 B-dul \\ Mărăşti, Bucureşti, România; florin.stanica@usamv.ro ( ${ }^{*}$ correspondingauthor)
}

\begin{abstract}
The present study presents the effect of two organo-mineral fertilizers: root fertilizer C011 and foliar fertilizer 411 bio-ionic liquids, on some vegetative and productive features of five new peach [Prunus persica (L.) Batsch] varieties introduced in Romania: 'Earlirich', 'Royal Estate', 'Rubirich', 'October Star' and 'Late Luka', grafted on GF 677 rootstock. The experimental plot located on a reddish preluvosol, have been established in 2008 with four planting systems: Tatura trellis, V planting system, Sibari Y and Vertical axe with different nutrition area/tree. Fertilization was applied on the beggining of June and August, 2010 and 2011 on the soil, locally on the tree rows (C011) and by foliar spraying (411). Trees vegetative growth was compared at the end of the vegetation period by number of fruit buds per unit trunk surface section (CM/TSS) with significant differences between types of crowns and the biggest values for 'Rubirich'; the total shoots length with significant differences between varieties. The influence of fertilization on trees productivity was apreciated by analyzing the yield and some typical productivy indexes. The studied parameters including the NPK uptake, have been significantly influenced by the variety 3.39\% Nt at 'Rubirich' in 2010 and 2.75\% Nt at 'Rubirich' in 2011 in Tatura trellis planting system.
\end{abstract}

Keywords: canopy, leaf, Prunus persica, shoot, trunk

\section{Introduction}

In modern orchards, the plant is the production unit that must meet several important requirements: to produce fruit immediately after planting; the planting to be amenable to high densities and to exploit such low volumes of soil; to capture and capitalize a larger amount of solar energy, to produce regularly and sustained high quality fruit (Stănică, 2011).

Pruning techniques adopted in the formation stage of the tree canopy for more efficient light use is the key to accelerating the beginning of the fruit production (Caruso et al., 2001).

Through modern techniques that reduce the number of cuts in the first years, by encouraging summer pruning at the expense of classic pruning made during the dormancy, a more balanced distribution of the growth and stimulation of vigorous fruit branches formation are obtained (DeJong et al., 2009).

Canopy forms studied, Tatura trellis, V planting system, Sibari Y and Vertical Axe, are commonly used in super intensive planting systems. The high density of trees per hectare, canopy opening allow easy maintenance works.

As with all other plants, peach trees requires at least 16 essential elements for optimum growth and productivity. A deficiency of any one of these nutrients can lead to problems with productions, fruit quality, vegetative growth or tree healty (Johnson cited by Desmond et al., 2010). A standard method for diagnosing the nutrient content for peach, is using mid-summer sample of mature, mid-shoot leaves. Batjer and Westwood (1958) found relatively constant values of most nutrients during the period from 100 to 125 days after bloom. They recommended this stable period for leaf sampling, when consistent values could be obtained from year to year (Johnson cited by Desmond et al., 2010). The method does have drawbacks and considerable efforts have been made in recent years to develop alternative approaches. A periode of 100 to 125 days after bloom is generaly too late in the season to apply any corrective measures for yield and fruit quality in that year. An early-season or even dormant sampling would be preferable (Sanz et al., 1992).

In the present study, it has been analyzed tree structure and the changes that occur after fertilization. The study combined a morphological evaluation with the NPK total forms determinations in the peach leaves.

The fertilizers used in study, C-011 $(0 \mathrm{~g} / 1 \mathrm{~N} ; 1.20 \mathrm{~g} / \mathrm{l}$, $\left.\mathrm{P}_{2} \mathrm{O}_{5} ; 1.20 \mathrm{~g} / 1 \mathrm{~K}_{2} \mathrm{O}\right) 2-2.5 \%$ and $411(1.80 \mathrm{~g} / \mathrm{l} \mathrm{N} ; 0.35 \mathrm{~g} / \mathrm{l}$ $\mathrm{P}_{2} \mathrm{O}_{5} ; 0.40 \mathrm{~g} / 1 \mathrm{~K}_{2} \mathrm{O}+$ Vitamin C) $1-1.5 \%$ have the concentrations of nutritive elements specific for vegetative fertilization. The two fertilizers were used 8-10 weeks after flowering.

The research aims to study the effect of different planting systems and organo-mineral fertilizers on the behaviour of some new peach tree varieties under the conditions of the Romanian plain. 
178

\section{Materials and methods}

\section{Plant material}

The present research was conducted in the experimental field of the Horticulture Faculty, University of Agronomic Sciences and Veterinary Medicine of Bucharest (lat $\left.44^{\circ} 26^{\prime} \mathrm{N}\right)$, Romania. The experimental plot located on a reddish preluvosol, in the conditions of a temperate-continental climate, have been established in 2008 with four planting systems Tatura Trellis, V planting system, Sibari $Y$ and Verticale Axe. The samples was represented by five peach varieties: 'Royal Estate,' 'Earlirich', 'October Star', 'Late Luka', 'Rubirich' grafted on 'GF 677' ( Prunus persica $\times$ Prunus dulcis). The applied planting distances were: Tatura trellis - $5.0 \times 1.0 \mathrm{~m}$ (Chalmers et al., 1978), V planting system - $5.0 \times 1.5 \mathrm{~m}$, Sibari Y $-4.5 \times 1.5 \mathrm{~m}$ (Chalmers et al. , 1978; Grappadelli et al., 1986; Caruso et al., 1997, 2003) and Vertical Axe - $4.0 \times 1.5 \mathrm{~m}$ (DeJong et al., 1994).

The trellis systems for Tatura Trellis and Sibari Y have been realised with protected pine poles, fixed in $\mathrm{V}$, at 10 $\mathrm{m}$ one from the other and four galvanised wires for each lateral side, disposed at $1 \mathrm{~m}$. For $\mathrm{V}$ planting system the trees have been sustained by bamboo canes fixed in $\mathrm{V}$ at 45 degrees angle. For the Vertical Axe system bamboo tutors have been used to support each tree. The irrigation system was made by dripping with one self compensating dripper for each peach tree.

The pruning treatments was specifically for each planting system.

Fertilization was achieved with organo-mineral fertilizers: root fertilizer C-011 (0 g/l N; $1.20 \mathrm{~g} / 1, \mathrm{P}_{2} \mathrm{O}_{5} ; 1.20$ $\mathrm{g} / \mathrm{K}_{2} \mathrm{O}$ ) with ground application and foliar fertilizer 411 (1.80 g/l N;0.35 g/l P $\mathrm{O}_{5} ; 0.40 \mathrm{~g} / 1 \mathrm{~K}_{2} \mathrm{O}+$ Vitamin C) with foliar application. The application of fertilizers was done at 8-10 weeks after flowering depending on the variety, at June $6^{\text {th }}, 2010$ and June $8^{\text {th }}, 2011$. The fertilizers were applied on the same day.

It should be noted that in 2010 the peach experimental plot was severely attacked by Taphrina deformans.

\section{Data analysis}

At the beginning of the vegetation period biometric measurements and observations were made concerning the trunk diameter, annual branches number and length and their typology.

Ten days after fertilization, corresponding to 70-90 days after flowering, samples consisting of shoots tips with
4-6 leaves have been collected. Leaf lamina has been used to determine the content of the macroelements.

The determination of leaves content in total forms was performed by wet mineralization-Hach Digesdahl method (Hach et al., 1987). Macroelements dosage was performed by Kjeldahl method for nitrogen determination, by spectrophotometric method for phosphorus and flam photometry for potassium (Hach, $1992 \mathrm{a}, \mathrm{b}$ ).

The same trees of each variety were measured in 2010 and 2011.

\section{Results and discussion}

Total lenght and number of one year fruit shoots

Annual shoot growth is a criterion that provides information on tree vigor. The trees productivity is the result of shoots growth and later of flower bud differentiation on those shoots (Bassi, 2003; Stănică, 2011)

The results obtained by biometric analyzes of five peach varieties annual growth under Tatura trellis training system were presented in Tab. 1 and the results are compared for two years.

It can be notice that in the first year of observations, the number of fruit shoots was lower than in the second year in all varieties examined, while their total length values decreased significantly in the second year.

The calculated correlation coefficients indicate a significant correlation between the $\mathrm{Nt}$ content of peach shoots and their lenght in 2010 and 2011 (Fig. 1).

\section{Number of fruit buds per unit trunk surface section}

Number of fruit buds reported to the trunk section area $\left(\mathrm{cm}^{2}\right)$ is an indicator used to express the optimum load of fruit buds reported to the tree vigor (Iacob, 2011; Voiculescu et al., 2006). Establishing optimum fruit load is one of technological tool with a constant impact on production and crop efficiency. The productivity index expressed as the ratio between the number of flower buds and trunk sectional area at the five peach varieties studied in four planting systems in 2010 was presented in Tab. 2 .

It can be observed significant differences between different canopies, the most representative being $\mathrm{V}$ planting system, due to the highest tree density, while the reverse was for Verticale Axe.

The ratio between flower buds number and trunk sectional area was significantly different among cultivars. The variety 'Rubirich' recorded the highest productivity index values in all four training systems.

Tab. 1. Total number and lenght of one year peach tree shoots in the Tatura trellis training system

\begin{tabular}{ccccccccccc}
\hline Variety & \multicolumn{2}{c}{ 'Royal Estate' } & \multicolumn{2}{c}{ 'Earlirich' } & \multicolumn{2}{c}{ 'October star' } & \multicolumn{2}{c}{ 'Late Luka' } & \multicolumn{2}{c}{ 'Rubirich' } \\
\hline Year & 2010 & 2011 & 2010 & 2011 & 2010 & 2011 & 2010 & 2011 & 2010 & 2011 \\
\hline $\begin{array}{c}\text { Total number of } \\
\text { shoots/tree }\end{array}$ & 99 & 168 & 58 & 100 & 88 & 112 & 75 & 92 & 140 & 152 \\
$\begin{array}{c}\text { Total length of } \\
\text { shoots }(\mathrm{cm})\end{array}$ & 1809 & 1770 & 1916 & 1543 & 1917 & 1450 & 1372 & 1079 & 3662 & 2400 \\
\hline
\end{tabular}


Tab. 2. Productivity index: ratio between flower buds number and trunk sectional area

\begin{tabular}{cccccc}
\hline Canopy & \multicolumn{5}{c}{ Fruit buds number/ trunk section area } \\
\hline Variety & 'Royal Estate' & 'Earlirich' & 'October Star' & 'Late Luka' & 'Rubirich' \\
\hline Tatura trellis & 62.63 & 39.73 & 27.89 & 47.15 & 77.20 \\
V planting system & 41.06 & 210.00 & 169.7 & 118.24 & 288.98 \\
Sibari Y & 52.42 & 40.63 & 147.98 & 128.92 & 177.93 \\
Vertical Axe & 77.27 & 20.89 & 130.50 & 71.42 & 314.76 \\
\hline
\end{tabular}

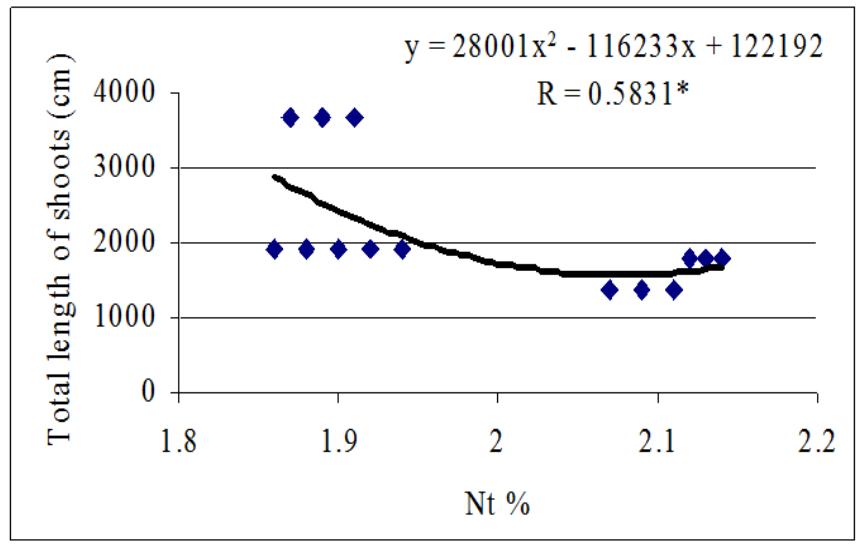

2010

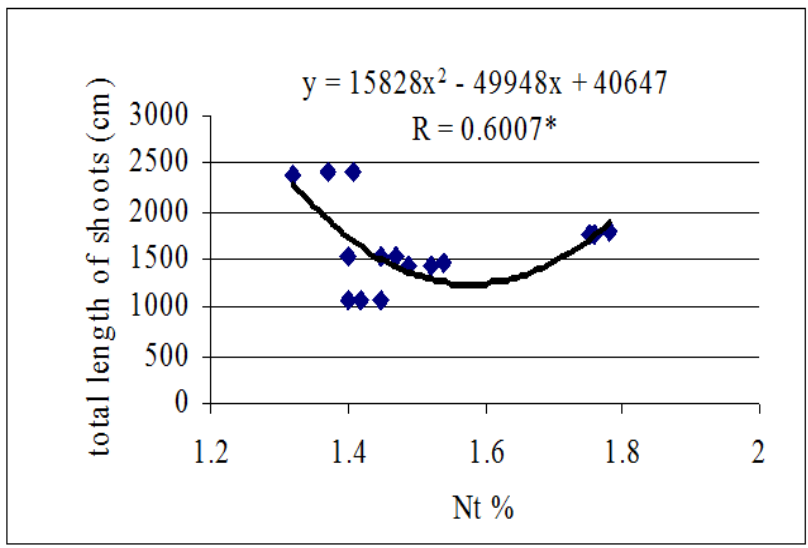

2011

Fig. 1. Correlation between the total number of shoots on the tree and their total length

The chemical composition of peach leaves

Tab. 3 presented the results obtained regarding NPK macro-elements accumulation (total forms \%) in peach leaves and shoots. Comparative results are presented for two years for the varieties studied in the Tatura trellis system.

The leaves content in $\mathrm{N}_{\mathrm{t}}(\%)$ at $10-12$ weeks after flowering varied between $3.01 \% \mathrm{Nt}$ for 'Late Luka'and 3.39\% $\mathrm{Nt}$ for 'Rubirich' variety in 2010. The values obtained were placed in the normal supply (3.0 to $3.5 \% \mathrm{Nt}$ ) compared with the limits cited in literature (Davidescu and Davidescu, 1992; Leece et al., 1971; Robinson et al., 1997 cited by Johnson, 2008; Weir and Cresswell, 1993).

In 2011, the values varied between $2.34 \% \mathrm{Nt}$ for 'Late Luka' and $2.75 \% \mathrm{Nt}$ for 'Rubirich' variety, being placed in the low supply range (Davidescu and Davidescu, 1992; Leece et al., 1971; Robinson et al., 1997 cited by Johnson, 2008; Weir and Cresswell, 1993). It is advisable to keep the leaf $\mathrm{N}$ concentrations slightly below 3.0\% (Johnson and Uriu, 1989).
The variation of leaves Pt content (\%), for all the studied varieties recorded in 2010, values between $0.510 \% \mathrm{Pt}$ for 'Late Luka' cultivar and $0.696 \%$ Pt for 'Earlirich' cultivar.

In 2011, the values varied between $0.292 \% \mathrm{Pt}$ for 'Late Luka' and $0.580 \%$ Pt for 'Rubirich', exceeding in the phenophase of 10-12 weeks from flowering, the content for a high supply $(>0.40 \%)$ indicated in literature (Leece et al., 1971; Robinson et al., 1997 cited by Johnson, 2008). High phosphorous can exacerbate a $\mathrm{Zn}$ deficiency situation (Ballinger et al., 1966 cited by Johnson, 2008). Taylor and Issell (1976), cited by Johnson (2008) found soil applications to be more effective than foliar applications at improving the phosphorous status of peaches. Healthy trees have usually between 0.14 and $0.25 \% \mathrm{Pt}$ (Robinson et al., 1997 cited by Johnson, 2008).

The limits of variation of $\mathrm{Kt}$ content were between $1.45 \%$ for 'Royal Estate' and $1.80 \%$ for 'Earlirich' in 2010 and $1.45 \%$ for 'Late Luka' and $2.10 \%$ for 'Rubirich' in 2011. The values match a low supply $(1.1-2.0 \% \mathrm{Kt}) \mathrm{com}-$

Tab. 3. Accumulation of NPK macro-elements - total forms (\%) in leaves ten days after the fertilization for peach varieties grown in Tatura trellis training system

\begin{tabular}{cccccccccccc}
\hline \multirow{2}{*}{$\%$} & \multicolumn{2}{c}{ 'Royal Estate' } & \multicolumn{2}{c}{ 'Earlirich' } & \multicolumn{2}{c}{ 'October Star' } & \multicolumn{2}{c}{ 'Late Luka' } & \multicolumn{2}{c}{ 'Rubirich' } \\
\cline { 2 - 27 } & 2010 & 2011 & 2010 & 2011 & 2010 & 2011 & 2010 & 2011 & 2010 & 2011 \\
\hline $\mathrm{Nt}$ & 3.26 & 2.36 & 3.29 & 2.60 & 3.37 & 2.56 & 3.01 & 2.34 & 3.39 & 0.646 & 0.580 \\
$\mathrm{Pt}$ & 0.674 & 0.353 & 0.696 & 0.535 & 0.65 & 0.430 & 0.510 & 0.292 & 1.65 & 2.10 \\
$\mathrm{Kt}$ & 1.45 & 1.81 & 1.80 & 2.00 & 1.60 & 1.50 & 1.50 & 1.45 & \\
\hline
\end{tabular}


The analysis of variance for total phosphorus accumulation in leaves of peach varieties grown in the four the planting systems show significant differences (Tab. 5). In the case of 'Royal Estate' variety the highest values are obtained on $\mathrm{V}$ planting system in leaves $(0.505 \% \mathrm{Pt})$ with significant differences compared to the other planting systems.

For 'Earlirich' there were more classes of value, in the first was situated with the highest accumulations in total $\mathrm{P}$, Tatura Trellis leaves $(0.535 \% \mathrm{Pt})$ and $\mathrm{V}$ system leaves $(0.522 \% \mathrm{Pt})$ followed by Sibari Y $(0.353 \% \mathrm{Pt}$ in leaves $)$ and Vertical Axe (0.325\% Pt in leaves).

For 'October Star' there were no significant differences in $\mathrm{Pt}$ accumulation in leaves given by the planting system, except the Sibari Y system with the value of $0.386 \% \mathrm{Pt}$.

For 'Late Luka' the highest values of Pt accumulations in leaves were in Vertical Axe system with of $0.498 \% \mathrm{Pt}$ and $\mathrm{V}$ planting system with $0.459 \% \mathrm{Pt}$, followed by the other two planting systems.

For 'Rubirich' there were significant differences. The planting system recommended in the case of accumulation of nutrients, namely phosphorus was Tatura trellis system with $0.580 \% \mathrm{Pt}$ in leaves.

The accumulation of total $\mathrm{K}$ in leaves, showed in the case of Royal Estate, high values represented by $1.89 \% \mathrm{Kt}$ for the $\mathrm{V}$ planting system and $1.81 \% \mathrm{Kt}$ for Tatura trellis planting system (Tab. 6).

For 'October Star' there were significant differences in $\mathrm{Kt}$ accumulation given by the planting system, the biggest content being registered in Sibari Y system, of $1.55 \% \mathrm{Kt}$. For 'Late Luka' the highest values have been recorded in the $\mathrm{V}$ planting system with accumulations of $1.70 \% \mathrm{Kt}$ and in the Vertical Axe system $(1.67 \% \mathrm{Kt})$.

\section{Conclusions}

In the climatic conditions of the Romanian Plain, on preluvosol soil, for peach crop foliar fertilization is recommended as an additional measure to complement the supply of fertilizers applied to the root. $\mathrm{N}$ content was framed in a normal supply, the $\mathrm{P}$ content in a high supply, while $\mathrm{K}$ was in small amounts. Number of fruit branches in the studied five peach varieties increased significantly in 2011, due to both fertilization and pruning carried out in spring and summer. In terms of productivity index expressed by the number of fruit buds per unit of trunk surface section, 'Rubirich' recorded highest values in all four planting systems, Tatura trellis, V system, Sibari Y and Vertical Axe. To obtain an optimal number of fruit shoots, keeping the tree health by phytosanitary treatments and summer pruning are necessary. The root fertilization is important but it is necessary to be supplemented by foliar fertilization in order to create a balance between N, P and K plant content during the vegetation period,

\section{Acknowledgements}

This research is part of Matei T.G. Ph.D thesis and is financed by the European Social Found - Operational Sectorial Program for Human Resources Development, Romania 2007 - 2013 POS-DRU/88/1.5/S/52614.

\section{References}

Ballinger WE, Bell HK, Childers NF (1966) Peach nutrition, 276-390 p. In: Childers NF (ed.). Nutrition of fruit crops, temperate, sub-tropical, tropical. Somerset press, Sommerville, New Jersey.

Bassi D (2003). Growth Habits in Stone Fruit Trees. Il Divulgatore, Bologna, Italy.

Batjer LP, Westwood MN (1958). Seasonal trend of several nutrient elements in leaves and fruits of 'Elberta' peach. Proc of the Am Soc for Hortic Sci 71:116-126.

Caruso T, Barone E, Di Vaio C (2001). Factors affecting tree crop efficiency in young peach trees: Rootstock vigour and training system. Acta Hort $557 \mathrm{p}$.

Caruso T, Di Vaio C, Guarino F, Motisi A, Nuzzo V (2003). Peach varieties for intensive plantations in southern Italy, 4451 p. In: Marra FP, Sottile F (Eds.). Proc IV Cong Nazionale sulla Peschicoltura Meridionale. Panuzzo Prontostampa, Caltanisseta, Italy.

Caruso T, Giovannini D, Marra FP, Sottile F (1997). Two new planting systems for early ripening peaches (Prunus persica L. Batsch): yield and fruit quality in four low-chilling cultivars. J Hortic Sci 72:873-883.

Chalmers DJ, van den Ende B, van Heek L (1978). Productivity and mechanization of the Tatura trellis orchard. Hortic Sci 13:517-521.

Davidescu D, Davidescu V (1992). Agrochimie horticolă. Bucureşti, $472 \mathrm{p}$.

DeJong TM, C Negron, Favreau R, Costes E, Day KR (2009). Using Concepts of Shoot Growth and Architecture to Understand and Predict Responses of Peach Trees to Pruning. VII Int. Peach Symposium, Leida.

DeJong TM, Day KR, DoyleJF (1994). The Kearney Agricultural Center perpendicular ' $\mathrm{V}$ ' (KAV-V) orchard system for peaches and nectarines. Hort Technol 4:362-367.

Desmond R, Bassi L, Bassi D (2010). The Peach. Botany, Production and Uses.

Grappadelli C, Brighenti L, Palara G, Ravaioli F, Sansavini S (1986). Esperienze su forme di allevamento del pesco per medie ed alte densita di impianto. Riv Frut 12:55-60.

Hach CC, Bowder BK, Kopelove AB (1987). More powerful peroxide Kjeldahl digestion method. J Assoc Anal Chem $70(5)$.

Hach CC (1992a). Hach Procedure Manuals. Digesdahl Digestion Apparatus Instruction Manuals $3^{\text {rd }}$ edition. Cat 23130:89. 
182

Hach CC (1992b). Hach Procedure Manuals. Agricultural Analysis Handbook. Cat 22546:08.

Iacob F (2011). Research on the main agro productivity characters on sour-cherry varieties grown in the N-E area of Romania, PhD Thesis. University of Agricultural Sciences and Veterinary Medicine Iaşi, Romania.

Johnson RS (2008). Nutrient and water requirements of peach trees. The peach botany, productions and uses, 303-332 p.

Johnson RS, Uriu K (1989). Mineral nutrition 68-81 p. In: LaRue JH, Johnson RS (Eds.). Peaches, Plums and Nectarines: Growing and Handling for Fresh Market. Univ of California, Div of Agriculture and Natural Resources (3331). Univ of California, Oakland, California.

Leece DR, Cradock FW, Carter OG (1971). Development of leaf nutrient concentration standards for peach trees in New South Wales. J Hort Sci 46:163-175.

Robinson JB, Treeby MT, Stephenson RA (1997). Fruits, vines and nuts, 349-382 p. In: Reuter DJ, Robinson JB (Eds.). Plant analysis, an interpretation manual, $2^{\text {nd }}$ edn. CSIRO Publishing, Collingwood, Australia.
Sanz M, Cavero J, Montanes L (1992). Relationships between yield and leaf nutrient contents in peach trees: early nutritional status diagnosis. J Plant Nutrition 15:14571466.

Stănică F (2011). Fruit Growing Technologies: Traditional, Modern and Organic. Second Balcan Fruit Symp. Pitesti. Acta Hort. (in press.).

Tayler BK, Issell LG (1976) Comparative effects of foliar- and root-applied phosphorus on one-year-old peach trees. Austr J Experim Agric Animal Husbandry 16:596-599

Voiculescu N, Hoza D, Spiță V (2006). Reference values of soil nutrient uptake in fruit. III-th part: $291 \mathrm{p}$.

Weir RG, Cresswell GC (1993). Plant Nutrient Disorders 3, Vegetable Crops. NSW Department of Agriculture. Inkata Press, Australia, 105p. 